\title{
Zika virus spreads across Americas as concerns mount over birth defects
}

\author{
Owen Dyer
}

Montreal

While a vaccine for dengue virus was approved this week in Mexico and the Philippines, dengue's lesser known cousin the Zika virus has ballooned into a public health crisis across large parts of Latin America.

Zika's rapid geographic spread would be causing less concern to public health authorities were it not for worrying evidence that the disease is less benign than initially thought. Hundreds of cases of Guillain-Barré syndrome have sprung up in the wake of Zika infection, but it is an explosion of microcephaly among infants born to infected women that has caused Brazil to declare Zika a "public health emergency of national importance."

Brazil's first confirmed Zika infection was in March 2015. Over the previous five years, the country of 204 million saw between 130 and 170 cases of microcephaly each year. In the first nine months of 2015 , this figure roughly doubled. In the past three months, over 2400 further cases have been reported.

The Pan American Health Organization (PAHO) issued an epidemiological alert on 1 December warning of a suspected link between $\mathrm{Zika}$ and neurological syndrome or congenital malformation, but it noted that final proof was lacking. ${ }^{1}$ The health ministries of Brazil and of Mexico, where Zika has also recently arrived, are no longer expressing any caveats and have said that the link is established.

In the three weeks since the PAHO alert was issued, the number of member countries reporting autochthonous Zika transmission has risen from nine to 12 , and the number of reported cases of microcephaly in Brazil has risen from 1248 to 2782.

At a press conference in Pernambuco, Brazil's hardest hit state, President Dilma Rousseff said that the federal government was "in a state of war" with the Aedes aegypti mosquito, bearer of the Zika virus. She said that units from the armed forces and civil defense were accompanying more than 100000 health workers in efforts to destroy breeding sites and educate citizens about the dangers of standing, stagnant water.

But an extensive anti-mosquito campaign aimed at reducing dengue and chikungunya was already in place and failed to stop Zika from causing disease in 500000 to 1.5 million Brazilian people this year, the health ministry has estimated. The typical presentation is a non-specific flu-like fever with rash,

conjunctivitis, and sometimes muscle or joint pain. There is no cure or vaccine. For each symptomatic case, there are about four asymptomatic infections. Many of the mothers of children with microcephaly reported no symptoms.
Scott C Weaver, director of the Institute for Human Infections and Immunity at the University of Texas and an expert in mosquito borne diseases, said that evidence indicated that Zika may spread more efficiently among human populations than dengue or chikungunya. "It's often noted that mosquito borne diseases are likely to become more widespread due to climate change, but in fact this process has already been happening for years due to socioeconomic factors such as air travel and trade," Weaver told The BMJ.

Zika virus is named after the Ugandan forest where it was first isolated in a rhesus monkey in 1947. It spread around that time to southeast Asia, where it was blamed for sporadic small infections but attracted little notice. The first major outbreak struck the Yap Islands of Micronesia in 2007. A bigger outbreak occurred in French Polynesia in 2013, where public health officials estimated infection rates of $70 \%$ on some islands. That was followed by reports of Guillain-Barré syndrome in adults but not of birth defects.

Since first appearing in the western hemisphere in February 2014, on Chile's Easter Island, Zika has spread the length and breadth of Latin America in 18 months. This month Colombia has reported more than 1000 new suspected or confirmed symptomatic cases each week.

Caribbean nations are preparing for the virus, and Weaver thinks that a few autochthonous cases will be seen in the southern United States next year. "But these are likely to be small, sporadic outbreaks of the sort we've seen with dengue. The North American lifestyle of using air conditioned cars to move between air conditioned office and home tends to limit the spread of these diseases here."

Zika's ultimate range in North America would depend on whether it can be carried only by A aegypti, which is limited to southern states, or can also be borne by Aedes albopictus, the Asian tiger mosquito, which in recent decades has invaded large regions of the world, including the entire eastern United States. Zika has already been carried by mosquitoes other than $A$ aegypti, and A albopictus has proved an efficient vector in laboratory tests.

The virus currently in Brazil seems to be Asian or Polynesian, not African, in origin. One theory presented by Brazilian researchers is that it entered the country during the 2014 football World Cup. ${ }^{2}$

Although cases of Zika have been declared in almost every Brazilian state, most were linked to particular urban epidemics, 
and the cases of microcephaly were also concentrated geographically. Brazil's annual rate of microcephaly has climbed from 5.7 per 100000 live births in 2014 to 99.7 per 100000 live births in 2015, the PAHO alert said, but the risk was much higher in the hardest hit cities, such as Recife and Salvador de Bahia.

"Don't get pregnant now: that's the most rational advice I can give," Claudio Maierovitch, director of the communicable disease surveillance department at the Ministry of Health, told reporters at a press conference last month. He later withdrew this advice.

Brazil changed its definition of microcephaly at the beginning of this month, from a head circumference at birth of $\leq 33 \mathrm{~cm}$ to $\leq 32 \mathrm{~cm} .{ }^{3}$ This would be expected to decrease the number of cases reported.

But the government is clearly bracing for a sharp increase in birth defects. Among the measures announced by President
Rousseff this month as part of the "national mobilization against microcephaly" is a plan to increase the number of care centers for people with congenital disabilities from 125 to $214 .^{4}$

1 Pan American Health Organization. Neurological syndrome, congenital malformations, and Zika virus infection. Implications for public health in the Americas-epidemiological alert. 1 Dec 2015 www.paho.org/hq/index.php?option=com topics\&view=article\&id=427\& Itemid=41484\&lang=en

2 Salvador FS, Fujita DM. Entry routes for Zika virus in Brazil after 2014 world cup: new possibilities. Travel Med Infect Dis 15 Nov 2015, doi:10.1016/j.tmaid.2015.10.004.

3 Brazil Ministry of Health. Nota sobre medida do perímetro cefálico para diagnóstico de microcefalia. 7 Dec 2015. http://portalsaude.saude.gov.br/index.php/o-ministerio/principal/ secretarias/svs/noticias-svs/21109-nota-sobre-medida-do-perimetro-cefalico-paradiagnostico-de-bebes-com-microcefalia-relacionada-ao-virus-zika.

4 Brazil Ministry of Health. Monitoramento dos casos de microcefalias no Brasil. http:// portalsaude.saude.gov.br/images/pdf/2015/dezembro/15/COES-Microcefalias---InformeEpidemiol--gico---SE-49---15dez2015---10h.pdf.

Cite this as: BMJ 2015;351:h6983

() BMJ Publishing Group Ltd 2015 